\title{
SPATIAL DISTRUBITON OF CHILDREN TREATED BY CANCER IN ZONGULDAK, TURKEY
}

\author{
Aysel Topan ${ }^{\mathrm{a} *}$, Dilek Bayram ${ }^{\mathrm{b}}$, Mustafa Özendi ${ }^{\mathrm{c}}$, Ali Cam ${ }^{\mathrm{c}}$, Özlem Öztürk ${ }^{\mathrm{d}}$, Tülay Kuzlu Ayyıldız ${ }^{\mathrm{a}}$, Hülya Kulakçı ${ }^{\mathrm{a}}$, Funda \\ Veren ${ }^{\text {a }}$ \\ ${ }^{a}$ BEU, School of Health, Department of Nursing, Zonguldak, Turkey - (ayskose@hotmail.com, tayyildiz67@ hotmail.com, \\ hulyakulak@yahoo.com, verfun2000@yahoo.com) \\ b BEU, Health Application and Research Center, Zonguldak, Turkey - (dilekbayrm@gmail.com) \\ ${ }^{c}$ BEU, Engineering Faculty, Department of Geomatics Engineering, Zonguldak, Turkey - (mustafa.ozendi@beun.edu.tr, \\ alicam193@gmail.com) \\ a Karabük University, School of Health, Department of Nursing, Karabük, Turkey - (zlemzturk@ hotmail.com)
}

\section{Commission VIII, WG VIII/2}

KEY WORDS: Child, Cancer, Geographical Information System

\begin{abstract}
:
This research is focused on the examination of child cancer cases in Zonguldak (Turkey) descriptively in epidemiological aspect thanks to GIS. Universe of the study is composed of 60 children between 0-19 years old, treated in Children Oncology Clinic of Health Application and Research Center in BEU. Whole universe was reached without selecting a sample in the study. Data were collected by using a form prepared by obtaining expert advice and they were applied to children and their parents at study dates. Results were expressed as percentages. Chi-Square test was used in intergroup comparisons, results were assessed within $95 \%$ confidence interval and $\mathrm{p}<0.05$ was considered as statistically significant. Variables that were used in the study were assessed, recorded in prepared data collection form and distribution maps were produced. When disease diagnosis of the children participated in the study were evaluated, it was observed that $33.3 \%(n=20)$ were being treated for ALL, $13.3 \%(n=8)$ for Medullablastoma and $11.7 \%(\mathrm{n}=7)$ for Hodgkin-nonHodgkin Lymphoma. It was detected that $31.7 \%(\mathrm{n}=19)$ were in Ereğli, 31.7\% ( $\mathrm{n}=19)$ were in Central district and $18.3 \%(n=11)$ were in Çaycuma, when the places where children were living were evaluated. Statistically significant difference was found $(\mathrm{p}=0.016)$ comparing disease diagnosis with living place, and overall distribution map of the number of cancer cases was produced in this context. This is the first research subjecting the distribution of cancer cases for Zonguldak province.
\end{abstract}

\section{INTRODUCTION}

Childhood Cancers (CC) are found among all cancers at a ratio of $2 \% .10 \%$ of deaths during whole childhood period below 15 years old are due to CC (Pizzo and Poplack, 2001). 8000 children get cancer diagnosis each year in the USA. Leukemia and brain tumours are the most prevalent cancers $(30 \%$ and $20 \%$, respectively). Even though deaths decreasing due to CC, number of cancer incidence increases in recent years. Incidence of ALL (Acute Lymphoblastic Leukemia) has increased by 27.4\% from 1973 until 1990.

Childhood cancers have many differences from adulthood cancers in clinical, biological and genetic aspects. In a study performed in the USA, the incidence of a new cancer in a population including one million people each year was reported to be 129.77 children and occurrence is more often between $0-5$ years old. It was found that the incidence of $\mathrm{CC}$ varies depending on the countries and geographical regions. For instance; ALL is seen more in China, Japan and USA, whereas it occurs less in Middle East and Africa. Again, lymphoma are more frequently seen in Africa, but it occurs less in Japan (Pizzo and Poplack, 2001).
The causes of childhood cancers are still being studied by many scientists (Landrigan et al., 1998). The most significant factors are familial inheritance, ultraviolet radiation, ionizing radiation, electromagnetic waves, chemical agents, viral infections, diet and interactions between children and environmental materials (Cocco, 2002; Cavdar, 1997; Buffer and Kyle, 1999). Early diagnosis has a significant importance in CC. Families have important responsibilities in this aspect (Demirbag et al., 2013).

This paper presents the first results of an ongoing epidemiological study. Zonguldak has hard coal mining area that do not only provide energy requirement for the iron and steel plants in Kdz. Eregli and Karabuk, and two thermal power plants in Catalagzi and new stations planned. Use of this high calorific fuel for heating houses and lack of taking many environmental precautions cause significant contamination in air, soil and water (sea and drinking water) in overall Zonguldak. Kdz. Eregli has one of the largest iron-steel industry of Turkey, and Caycuma is an important area with small and medium sized industrial enterprises for the province. As understood from the studies about CC, environmental and chemical factors are important factors in the development of CC. It is required to give attention to the regions including the cases and the environmental characteristics. Therefore, the aim

\footnotetext{
* Corresponding author
} 
of this study is to examine cancer cases observed in children living in Zonguldak epidemiologically with the help of GIS.

\subsection{Geographical Information Systems and Their Use in} Epidemiology

Geographical Information Systems (GIS) have a very wide application area. GIS is an information system carrying out the functions as collection, storage, processing and presentation of geographical and attribute information obtained by geospatial observations (Yomralıoğlu, 2000). Although development of GIS is based on 1960s in modern means, the first example of GIS application is the epidemiological application created by John Snow in order to detect cholera epidemic in London (UK). Snow marked cholera cases emerged in 1854 on the map by lines for each house. He thought that cholera bacteria caused these cases and determined that the nearest water pump near these cases was a pump in Broad Street and these people provided their drinking water from this pump. He applied to municipality to ask for blocking this pump. After the blockage, a significant decrease was seen in cholera cases (StanwellSmith, 2013). Snow's study is a simple but effective example that reveals the importance of map and thus, the use of geospatial information in epidemiological studies.

Geospatial information for different classes (e.g. buildings, roads, satellite images, etc) is expressed by separate layers in GIS. GIS is a highly useful and necessary tool that performs procedures such as combining different numerical data, making geospatial queries, being suitable for automation, visual presentation, manipulation, making geostatistical analyses, giving prospective decisions and estimating possible situations against designed scenarios (GIS Lab, 2014).

Although the importance of GIS is increasing in epidemiological studies day by day, use of GIS in epidemiological studies is not still carried out systematically and within a particular policy framework in Turkey. For instance; when cancer-related studies are examined, it is observed that these are some national projects carried out by universities and they do not show continuity. Examples from these studies on cancer are as follows: in a study by Colak and Yomralığlu (2007) and Yomralığlu et al. (2009) performed in Trabzon city, a possible relationship between cancer types and land cover (such as agriculture, forest, residential) and heights was investigated. The distribution of cancer cases in Konya city in 2006 was examined by GIS by Özkan and Güngör (2007). Günay and Saraç (2010) have explained compilation and standardization of data and the methods used for drawing maps by the examples in Konya City for April-September 2005 and country-wide for 2002-2006. Güngör and Özkan (2011) have performed a study on cancer cases in Kütahya in 2007 and on the distribution of death rates. Türk (2013) strives to investigate cancer cases in Sivas between 2007-2010.

\section{MATERIALS AND METHOD}

This is a descriptive epidemiological study evaluating cancer cases with GIS. The study is conducted with 60 children between 1-19 years old who were diagnosed as cancer and treated in Children Oncology Clinic in Bulent Ecevit University between 15.03.2014-31.01.2016. Whole universe was reached in the study without selecting a sample. Data collection is performed by a form which was prepared by taking expert advice and which is composed of a total of 20 items and including sociodemographic characteristics, existing disease and treatment-related conditions of the children and their families was used as the data collection tool. Form was applied to the children and the parents in children oncology clinic at the dates of the study.

SPSS 16 for Windows was used for data analysis. Results were expressed as percentages. Chi-Square test was used for intergroup comparisons. Results were assessed within 95\% confidence interval and $\mathrm{p}<0.05$ was considered as statistically significant.

Database of the study and the map showing counties of Zonguldak province were associated in ArcGIS software, and distribution of cancer cases were presented in map format. Variables used in the study were evaluated, recorded in prepared data collection form and distribution maps were produced. In addition all necessary institutional permits and ethics committee approval were taken in order to perform the study.

\section{RESULTS OF DATA ANALYSIS}

It was found that $35 \%(n=21)$ of the children included in the study were between $5-8$ years old, $51.7 \%(n=31)$ were males, $48.3 \%(\mathrm{n}=29)$ were females, $36.7 \%(\mathrm{n}=22)$ had two siblings, $90 \%(n=54)$ had a housewife mother, 56.7\% ( $n=34)$ had a freelancer father, the mothers of $40 \%(n=24)$ were between 3640 years old and fathers of $31.7 \%(n=19)$ were between $41-45$ years old.

It was detected that $78.3 \%(n=47)$ of the children in the study did not have a cancer history in their families. When disease diagnosis of the children were examined, the most observed three types are that $33.3 \%(n=20)$ was treated for ALL, $13.3 \%$ $(n=8)$ for Medullablastoma and $11.7 \%(n=7)$ for HodgkinNonHodgkin Lymphoma. When the counties where the children were living were investigated, it was found that $31.7 \%(n=19)$ were in Eregli, 31.7\% $(\mathrm{n}=19)$ in Center and $18.3 \%(\mathrm{n}=11)$ in Caycuma. When disease diagnosis was compared based on the county, it was detected that there was a statistical significance $(\mathrm{p}=0.016)$. General distribution map of cancer cases was shown in Figure 1.

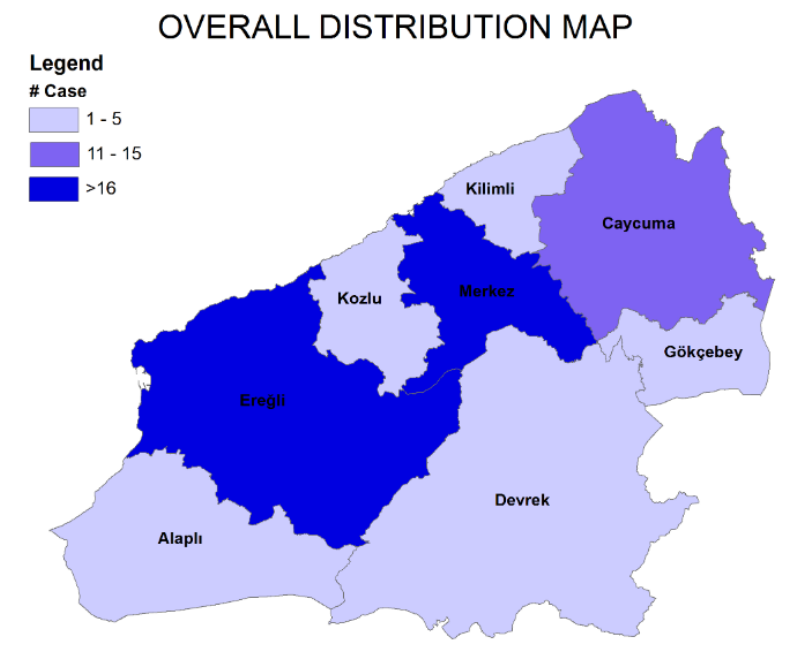

Figure 1. Overall distribution map of cancer cases

When distribution maps of the children included in the study were examined based on their residence, it was seen that number of cancer cases in Kdz. Eregli and Center were the highest $(n=19)$. 


\section{DISCUSSION}

Children constitute a significant group who are affected by physical, biological and social environment. 14 million children smaller than 5 years old die due to unhealthy drinking water, insufficient sanitation, environmental pollution, common diseases and starvation in developing countries each year (Guler, 2001). Protection of children from environmental chemicals is one of the important problems in modern societies (Landrigan et al., 1998). Incidence of childhood cancers can never be decreased down to zero level, but many of them can be avoided and kept at acceptable levels if sufficient protection measures are taken. Preventable childhood cancers constitute a significant public health issue.

The jobs of parents are also important factors in childhood cancers. In the study by Reynolds et al. (2003), it was found that the children of fathers who were working with benzene and carbontetrachloride, working in paint and auto repairs and who were exposed to ionizing radiation, electromagnetic field, hydrocarbon and metals and the mothers who were working in beauty centres, textile and dry cleaning jobs were more susceptible to develop leukemia (Colt and Blair, 1998). In a study in China, ALL development risk was found to be 1.8 due to pesticide interaction since their mothers were working in an agriculture-related job, and it was also detected that pesticide interaction during pregnancy has increased ALL risk by 3.5 -fold (Zahm and Ward, 1998). In our study, mothers of $90 \%(\mathrm{n}=54)$ of children were found to be housewives and fathers of $56.7 \%$ $(n=34)$ were freelancers; and in contrary to other studies, no statistically significant difference was observed between parents' occupation and children's disease diagnosis ( $p>0.05)$. However, it can be concluded that both all and ALL cases were accumulated in Centre, Kdz. Ereğli and Çaycuma, the most three industrial areas, in accordance with the findings of Pizzo and Poplack (2001). This facet can be observed from Figure 2 that presents geographical distribution of individual cancer types.

In the study by Reynolds et al. (2003) in California, childhood cancers which were associated with hazardous air pollutants were investigated. In conclusion, it was found that childhood cancers especially leukemias were closely associated with hazardous air pollutants. In the study by Landrigan et al. (2002) investigating incidence, prevalence, mortality and cost of chemical substance - related childhood cancers in USA, it was detected that environmental chemical substances were a source of $100 \%$ poisoning, $30 \%$ asthma, $5 \%$ cancer and $10 \%$ neurobehavioral impairment. In addition, the cost of annual poisoning, asthma, childhood cancers and neurobehavioral impairment were calculated as 43.3, 2, 0.3 and 9.2 billion dollars, respectively. This cost was directly medical expenses; it did not include indirect expenses as pain, suffering and late complications. The cost of children disease associated with environmental factors was high, but prevention methods were easier and cheaper (Landrigan et al., 2002).

In Environmental Threat to Children Health: Asia Perspective meeting including 15 countries in Philippines in April 2000, it was told that children in Asia were more affected by environmental chemicals. Especially poor children in poor countries were under more risk. Children below five years old are more affected, normal development of these children is not completed due to malnutrition. Safe water is not sufficient; infectious diseases along with contaminated food have a big threat on children. No legal regulations were done against environmental agents in these countries. Education is not adequate and risk awareness was not developed. It is estimated that 25 million people will suffer from cancer and 900 thousand people will have skin cancer in Bangladesh in the future since drinking water is contaminated with arsenic; and most of them are children. Although it was prohibited, hazardous and permanent pesticides, especially DDT are being used in agriculture in Indonesia. In a study performed in Cambodia, $23 \%$ of children between $6-12$ years old were complaining about skin lesions due to pesticides. Toxic substance interaction of children workers who are working with painting etc. in Asia was increased (Carpenter et al., 2000).

Due to the interactions with synthetic chemicals with a high production capacity which were produced in recent 50 years, children are under high risk. Most of these chemicals are commonly used as consumer products and they are distributed around. As a result of environmental pollution with these chemicals, children are affected; because their biological sensitivity are delicate. A comprehensive, national, childrenbased agenda called Children's Environmental Health NetworkCEHN was formed in order to protect children from environmental diseases. Agenda should be aware about the sensitivity of children against environmental toxic substances and do the following: it should focus on new studies for prevention, should make health risk assessments for children and develop policies for this, start a campaign that train public, healthcare professionals and policymakers about environmental diseases and CEHN should be promoted to establish national environmental health research centres for children for a longterm and fixed investment in order to settle this agenda (Landrigan et al., 1998).

In 1979 in USA, the relationship between childhood cancers and high-voltage lines was investigated in 344 children at 18 years old and it was reported that leukemia in children highly increased as proximity of the lines increased. It was also reported that the incidence of childhood cancers increased 2fold in the houses which were 150 meters near to 200 kilovolt high-voltage line in Sweden in 1982. Positive correlation between electromagnetic fields and cancer cases was revealed in many studies (Düzgün, 2009).

Similar to the studies mentioned above, higher incidence of cancer cases in Centre, Kdz. Ereğli and Çaycuma counties in our study may be related with the factories in those regions and the chemicals derived from those factories. When some environmental studies held in Zonguldak city were investigated, validity of this proposed thesis becomes stronger. For instance; a research performed by Uyar and Ören (2012) in Zonguldak city has revealed that the amount of arsenic was higher than European countries excluding Italy due to Catalağzı Thermal Power Plant (CATES), Ereğli Iron and Steel Station (ERDEMIR), the use of coal for heating purposes and trafficderived emissions (Uyar and Ören, 2012). In another study by Uyar et al. (2009), amounts of heavy metals in Zonguldak and Kdz. Ereğli were detected to be higher than Europe (Uyar, 2009). Polycyclic aromatic hydrocarbons (pah) are significant carcinogens (Alver et al., 2012). In a study carried out by Tağıl and Menteşe (2012), the relationship between air pollutants (PM10 ve SO2) in Zonguldak and respiratory tract disorders were revealed between 2006-2009. İncivez and Bahçelievler districts were detected as cold regions (regions including few cases) and Meşrutiyet and Baştarla districts were detected as hot regions (regions including more number of cases). The reason why more cases were seen in Meşrutiyet and Baştarla districts 

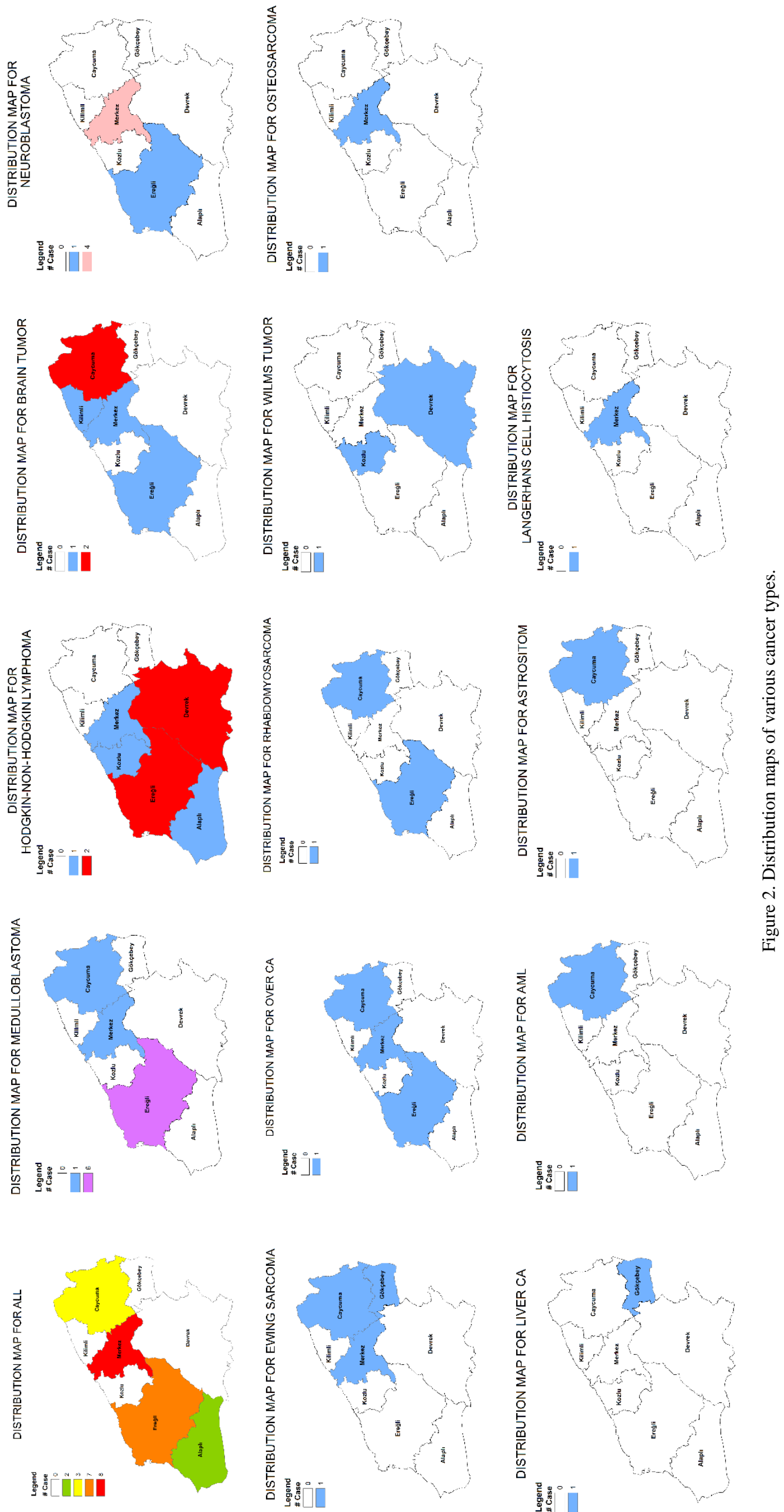
compared to the others was associated with the geographical locations of these districts. However, they have declared that variability of the number of cases in neighbourhoods was associated with variable topography of the region (Tağıl and Menteşe, 2012). In a study performed by Çabuk et al. (2014), amount of pah in Zonguldak Centre and Kdz. Ereğli was detected and 6-fold less number of pah were found in Kdz. Ereğli compared to Zonguldak. The reason of this is explained by the fact that coal is still used in Zonguldak Centre for heating purposes, but natural gas is highly used in Kdz. Ereğli instead (Cabuk et al., 2014). Zeydan et al. (2014) have determined PM10 concentrations with the help of GIS.

Geospatial distribution and frequency of cancer cases, which are the major health effects of this pollution, should be followed and necessary precautions should be taken by associating them with possible factors. Implementation of such a research is only provided in GIS with geostatistical tests.

In this study, it was first aimed to build up a GIS base which is comprising a numerical county-based map and database, and a detailed geostatistical analysis could not be performed due to the following limitations:

1. Cases were only county-based. A more detailed geospatial distribution map can be obtained if they can be village or district-based.

2. In case of a more detailed detection of the locations of the cases, their relationships with environmental factors (energy transmission lines, industrial institutions, water and sewage system, atmospheric pollutants, etc.) will be established statistically.

\section{CONCLUSIONS}

When disease diagnosis was compared based on the county, it was found that there was a statistically significant difference ( $\mathrm{p}=0.016$ ). However; as it was mentioned in discussion part, GIS-based epidemiological studies do not only provide information about geospatial distribution and temporal spread of the cases, but also they can reveal their relationship with environmental factors geostatistically. However; it is required to know geographical locations of the information regarding the cases as well as the environmental factors in detail. This preliminary study will allow elimination of deficiencies mentioned above and implementation of continuous analyses. Thus, it will be possible to follow CC and take precautions. The future cases must be monitored since one of the main environmental agent caused by usage of coal mines in household heating is being transferred to natural gas providing fresh-air.

\section{REFERENCES}

Alver, E., Demirci, A., Özcimder, M., 2012. Polisiklik aromatik hidrokarbonlar ve sağlığa etkileri. Mehmet Akif Ersoy Üniversitesi Fen Bilimleri Enstitüsü Dergisi, (3), pp. 45-52.

Buffler, P.A., Kyle, A.D., 1999. Carsinogen risk assesment guidelines and children. Environ Health Perspect, (107), pp. 286-288.

Carpenter, D.O., Chew, F.T., Damstra, T., Lam, L.H., Landrigan, P.J., Makalinao, I., Peralta, G.L., Suk, W.A., 2000. Environmental threats to the health of children: The Asian perspective, Environ Health Perspect, (108).
Cocco, P., 2002. On the rumors about the silent spring. Review of the scientific evidence linking occupational and environmental pesticide exposure to endocrine disruption health effects. Cad. Saude Publica, (18), pp. 379-402.

Colt, J.S., Blair, A., 1998. Parental occupational exposures and risk of childhood cancer. Environ Health Perspect, (106), pp. 909-925.

Çabuk, H., Kılıç, M.S., Ören, M., 2014. Biomonitoring of polycyclic aromatic hydrocarbons in urban and industrial environments of the Western Black Sea Region, Turkey. Environmental Monitoring and Assessment, (186), 1515-1524.

Çavdar, A.O., 1997. Gelişmekte olan ülkelerde çocukluk kanserleri. (Araştırma Monografisi). (TÜBİTAK), 1997.

Çolak, H.,E., Yomralığlu, T., 2007. Coğrafi bilgi sistemleri ile istatistiksel kanser haritalarının üretilmesi: Trabzon örneği, "TMMOB Harita ve Kadastro Mühendisleri Odası 11. Türkiye Harita Bilimsel ve Teknik Kurultayı", Ankara, Turkey.

Demirbağ. B.,C., Kürtüncü, M., Güven, H., 2013. Knowledge of Turkish mothers with children in the 0-13 age group about cancer symptoms, Asian Pacific J Cancer Prev, 14 (2), pp.1031-1035.

Füzgün, S., 2009. Elektromanyetik alanların insan sağlı̆̆ üzerindeki zararlı etkileri. Çukurova Üniversitesi Fen Bilimleri Enstitüsü Yüksek Lisans Tezi, Adana, Turkey.

GIS Lab, 2014. Geographic Information System Research and Development Laboratory, Karadeniz Technical University, http://www.gislab.ktu.edu.tr.

Güler, Ç., Çobanoğlu, Z., 2001. Çocuk ve çevre, Çevre Să̆lı̆ Temel Kaynak Dizisi, (23).

Güngör, C., Özkan, G., 2011. CBS kullanımı ile kanser ve ölüm oranları haritaları: Kütahya ili örneği, "TMMOB Coğrafi Bilgi Sistemleri Kongresi”, Antalya, Turkey.

Landrigan, P.J., Carlson, J.E., Bearer, C.F., Cranmer, J.S., Bullard, R.D., Etzel, R.A., Groopman, J., McLachlan, J.A., Perera, F.P., Reigart, J.R., Robison, L., Schell, L., Suk, W.A., 1998. Children's health and environment: a new agenda for prevention research. Environ Health Perspect, (106), pp.787794.

Landrigan, P.J., Schechter, C.B., Lipton, J.M., Fahs, M.C., Swartz, J., 2002. Environmental pollutants and disease in american children: estimates of morbidity, mortality and costs for lead poisoning, asthma, cancer and developmental disabilities. Environ Health Perspect, (110).

Özkan, G., Güngör, H.C., 2007. CBS'nin sağlık alanında kullanımı ve örnekleri, "TMMOB Harita ve Kadastro Mühendisleri Odası Ulusal Coğrafi Bilgi Sistemleri Kongresi”, Trabzon, Turkey.

Pizzo, P.A., Poplack, D.G., 2001. Principles and practice of pediatric oncology. Lippincott Williams \& Wilkins.

Reynolds, P., Von, Behren J., Gunier, R.B., Goldberg, D.E., Hertz, A., Smith, D.F., 2003. Childhood cancer incidence rates and hazardous air pollutants in California: an exploratory analysis. Environ Health Perspect, (111). 
Stanwell-Smith, R., 2013. A brief introduction to the remarkable Dr John Snow. Perspectives in Public Health, 133, 237.

Tağıl, Ş., Menteşe, S., 2012. Zonguldak'ta hava kirliliği (pm10 \& so2) ile ilişkili olarak seçilmiş solunum yolu hastalıklarının zamansal ve mekânsal değişimi. Balıkesir Üniversitesi Sosyal Bilimler Enstitüsü Dergisi, 15, pp. 3-18.

Türk, T., 2013. Investigating environmental health studies using geographical information systems: cancer case study. Polish Journal of Environmental Studies, 22 (5), 1505-1517.

Uyar, G., Avcil, E., Ören, M., Karaca, F., Öncel, M.S., 2009. Determination of heavy metal pollution in Zonguldak (Turkey) by moss analysis (hypnum cupressiforme). Environmental Engineering Science, 26,pp. 183-194.

Uyar, G., Ören, M., 2012. Coğrafi bilgi sistemi (CBS) haritalama tekniğinin Zonguldak ve çevresindeki atmosferik arsenik kirlilik belirleme çalışmalarında kullanılması, "IV. Uzaktan Algilama ve Coğrafi Bilgi Sistemleri Sempozyumu (UZAL-CBS 2014)", Zonguldak, Turkey.

Yomralığlu, T., 2000 Coğrafi bilgi sistemleri, temel kavramlar ve uygulamalar, Akademi Kitabevi, İstanbul, pp. 479.

Yomralığlu, T., Çolak, E.H., Aydınoğlu, A.C., 2009. Georelationship between cancer cases and the environment by GIS: a case study of Trabzon in Turkey. International Journal of Environmental Research and Public Health, (6), 3190-3204.

Zahm, S.H., Ward, M.H., 1998. Pesticides and childhood cancer. Environ Health Perspect, (106), pp. 893-907.

Zeydan, Ö., Yıldırım, Y., Karademir, A., Durmuşoğlu, E., 2014. Hava kalitesi modellenmesinde coğrafi bilgi sistemlerinin kullanımı: zonguldak örneği, "V. Uzaktan Algılama ve Coğrafi Bilgi Sistemleri Sempozyumu (UZAL-CBS 2014)”, İstanbul, Turkey. 